\title{
Analisa Kekuatan Sekat Bergelombang Kapal Tanker Menggunakan Metode Elemen Hingga
}

\author{
Zaki Rabbani, Achmad Zubaydi, dan Septia Hardy Sujiatanti \\ Departemen Teknik Perkapalan, Fakultas Teknologi Kelautan, Institut Teknologi Sepuluh Nopember \\ (ITS) \\ e-mail: zubaydi@na.its.ac.id, septi@na.its.ac.id
}

\begin{abstract}
Abstrak-Pemasangan sekat bergelombang dalam tangki muat kapal tanker memiliki keuntungan dalam hal permbershan tangki dan penambahan kapasitas tangki muat. Pada tangki muat yang berukuran besar perlu dilakukanperlu dilakukan pemasangan konstruksi tambahan berupa lower stool dan diafragma sekat. Dalam sisi lain, pemasangan konstruksi tersebut dapat mengurangi volume tangki dan mengganggu proses pembersihan tangki. Penelitian ini akan membahas analisis kekuatan sekat bergelombang dengan konstruksi tambahan berupa lower stool dan diafragma sekat untuk mendapatkan ukuran konstruksi yang optimum. Data sekat bergelombang diperoleh dari data konstruksi kapal tanker 17500 LTDW dengan tinggi lower stool $1280 \mathrm{~mm}$ dan tebal diafragma sekat $14 \mathrm{~mm}$. Dari data tersebut ditentukan variasi tinggi lower stool sebesar $895 \mathrm{~mm}, 1280 \mathrm{~mm}$, dan $1790 \mathrm{~mm}$; serta tebal diafragma sebesar $14 \mathrm{~mm}, 13 \mathrm{~mm}$, dan $11 \mathrm{~mm}$. Analisis dilakukan pada model variasi sekat bergelombang menggunakan metode elemen hingga. Dari proses analisis diperoleh nilai tegangan maksimum, deformasi maksimum, berat, dan volume konstruksi sekat. Tegangan maksimum terkecil terjadi pada tinggi lower stool $1790 \mathrm{~mm}$, sedangkan perubahan ketebalan tidak berpengaruh pada tegangan maksimum konstruksi sekat. Nilai deformasi maksimum terkecil terjadi pada tinggi lower stool $1790 \mathrm{~mm}$, dan tebal diafragma sekat $14 \mathrm{~mm}$. Variasi yang memiliki berat paling rendah memiliki tinggi lower stool $895 \mathrm{~mm}$, dengan tebal diafragma $11 \mathrm{~mm}$. Volume tangki muat mengalami pengurangan terendah pada variasi tinggi lower stool $895 \mathrm{~mm}$, dan tebal diafragma sekat $11 \mathrm{~mm}$. Perhitungan tegangan ijin menunjukkan bahwa variasi dengan tinggi lower stool $895 \mathrm{~mm}$ tidak memenuhi kriteria. Dengan demikian, ukuran variasi mencapai nilai optimum pada tinggi lower stool $1280 \mathrm{~mm}$ dengan tebal diafragma $11 \mathrm{~mm}$. Konstruksi tersebut memiliki nilai tegangan maksimum $278 \mathrm{MPa}$, deformasi maksimum sebesar $8,283 \mathrm{~mm}$, berat konstruksi 59,167 ton, dan volume konstruksi 79,548 $\mathrm{m}^{3}$.
\end{abstract}

Kata Kunci-Analisis Kekuatan, Lower Stool, Metode Elemen Hingga, Sekat Bergelombang.

\section{PENDAHULUAN}

CEKAT bergelombang merupakan jenis konstruksi sekat Nyang sering dipasang pada ruang muat kapal yang membawa muatan curah. Penggunaannya dalam kapal dengan muatan curah memiliki keuntungan dalam hal kapasitas ruang muat yang tidak berkurang karena konstruksi penguatan pada sekat bergelombang berupa lekukan yang dibuat pada pelat sekat. Pemasangan sekat bergelombang selain pada ruang muat kapal yang mengangkut muatan curah akan mengurangi kapasitas ruang yang dapat digunakan.

Pada kapal yang mengangkut muatan curah cair seperti tanker, sekat bergelombang memiliki keuntungan lain yaitu mempermudah proses pembersihan tangki. Proses pembersihan tangki menjadi lebih mudah dan lebih efektif dengan tidak adanya bagian yang tertutupi oleh konstruksi sekat seperti pada sekat berpenegar.

Pemasangan sekat bergelombang pada kapal dengan tangki muat berukuran besar memerlukan konstruksi tambahan untuk menambah kekuatan sekat. Konstruksi tambahan yang dipasang berupa lower stool dan diafragma sekat.

Penggunaan konstruksi tambahan tersebut dapat mengurangi efektivitas pemasangan sekat bergelombang karena dapat mengurangi volume tangki muat dan menghambat proses pembersihan tangki.

Untuk mendapatkan volume tangki yang maksimal dan mengurangi kemungkinan terhambatnya proses pembersihan tangki maka diperlukan ukuran yang optimum untuk konstruksi tambahan berupa lower stool dan diafragma sekat. Oleh karena itu, akan dilakukan analisis kekuatan konstruksi sekat bergelombang sehingga diperoleh ukuran konstruksi tambahan yang optimum.

\section{STUDI LITERATUR}

\section{A. Sekat Bergelombang}

Sekat bergelombang merupakan jenis konstruksi sekat yang terdiri dari pelat-pelat paralel dan dihubungkan oleh pelat miring pada tiap ujungnya. Kedua pelat tersebut memiliki kekuatan yang sama dalam menahan tekanan cairan dan keduanya dapat memiliki ketebalan yang sama dengan lebar yang sama. Dalam hal itu, sekat bergelombang bisa dibuat dari satu lembar pelat yang dibentuk dengan cara ditekuk [1]

\section{B. Elemen Sekat Bergelombang}

Satu elemen sekat bergelombang terdiri dari dua pelat bilah (web plate) yang menghubungkan dua pelat hadap (face plate) yang berdekatan. Dalam satu elemen sekat bergelombang, pelat hadap disusun secara paralel dan memiliki dimensi lebar hanya setengah lebar pelat hadap sesungguhnya [2]. Ilustrasi elemen sekat bergelombang dengan komponen dimensi 
ukurannya ditunjukkan pada Gambar 1.

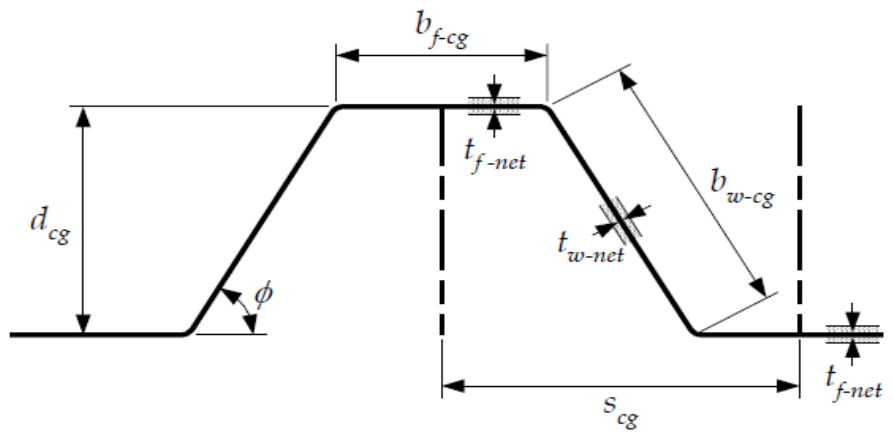

Gambar 1. Elemen sekat bergelombang[2]

\section{Konstruksi Lower Stool}

Lower stool merupakan sebuah struktur yang memiliki bentuk seperti kotak dan berfungsi untuk menopang sekat bergelombang pada ujung bawah sekat. Konstruksi stool dipasang pada kapal berukuran besar yang menyebabkan bentangan sekat berkurang dan menambah kekuatan sekat [3]. Pemasangan lower stool diwajibkan untuk kapal tanker dengan tinggi tangki muat lebih dari $16 \mathrm{~m}$ [2].

\section{Konstruksi Diafragma Sekat Bergelombang}

Diafragma sekat merpakan konstruksi yang terdiri dari pelat datar yang dipasang pada sekat bergelombang pada ketinggian tertentu. Pada sekat bergelombang dengan lekukan pada arah vertikal, beban yang terjadi sepanjang lekukan sekat akan memungkinkan lekukan sekat akan melipat ke arah horizontal. Oleh karena itu, diperlukan pemasangan diafragma sekat yang berlaku sebagai penegar horizontal yang menambah kekuatan melintang sekat bergelombang [4]. Diafragma sekat dipasang pada sekat bergelombang seperti yang terlihat pada Gambar 2.

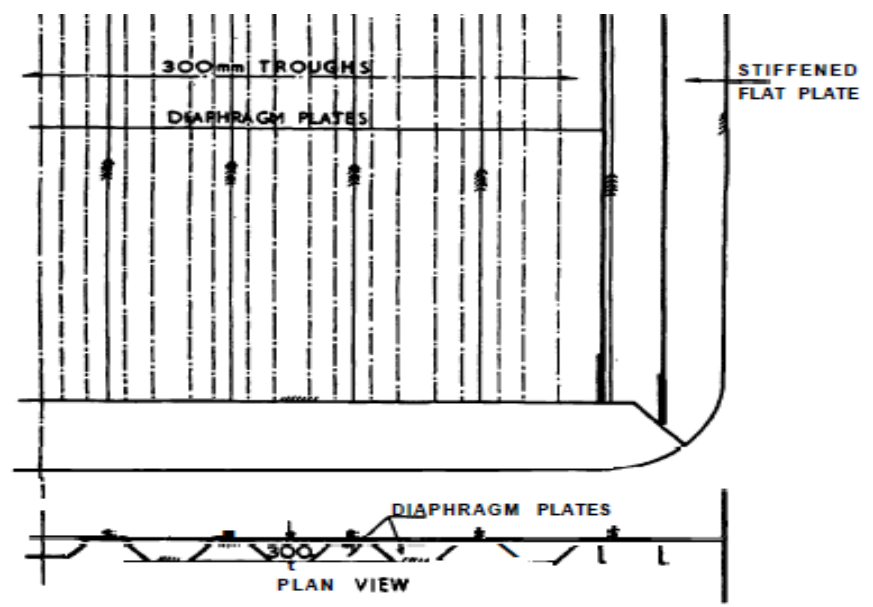

Gambar 2. Pelat diafragma yang dipasang pada sekat bergelombang pada ketinggian tertentu [4]

\section{E. Beban Lokal Statis Muatan}

Pembebanan akibat muatan dihitung menggunakan tekanan hidrostatis tangki dan tekanan testing tangki. Beban pada konstruksi sekat bergelombang dihitung menggunakan persamaan (1), (2), dan (3).

$$
\begin{aligned}
& P_{\text {in-tk }}=\rho \times g \times z_{t k} \\
& P_{\text {in-test }}=\rho_{s w} \times g \times z_{t e s t} \\
& P_{\text {in-test }}=\rho_{s w} \times g \times z_{t k}+P_{\text {valve }}
\end{aligned}
$$

Dimana, $P_{\text {in-tk }}$ adalah tekanan hidrostatis tangki; dalam $\mathrm{kN} / \mathrm{m}^{2}$, $P_{\text {in-test }}$ adalah tekanan testing tangki; dalam $\mathrm{kN} / \mathrm{m}^{2}, P_{\text {valve }}$ adalah tekanan katup; dalam $\mathrm{kN} / \mathrm{m}^{2}, \rho$ adalah massa jenis muatan dalam tangki; dalam ton $/ \mathrm{m}^{3}, \rho_{s w}$ adalah massa jenis air laut; dalam ton $/ \mathrm{m}^{3}, g$ menyatakan gaya gravitasi; dalam $\mathrm{m} / \mathrm{s}^{2}, z_{t k}$ adalah jarak vertikal titik acuan pembebanan ke ujung atas tangki; dalam $\mathrm{m}$, dan $z_{\text {test }}$ adalah diambil nilai terbesar antara jarak vertikal titik acuan pembebanan ke 2,4 $\mathrm{m}$ diatas ujung atas tangki, atau ke ujung atas pipa limpah; diambil dalam m. Dari (1), (2), dan (3) diambil nilai terbesar untuk diaplikasikan sebagai beban pada struktur [2].

\section{F. Metode Elemen Hingga}

Rujukan [5] menjelaskan analisis menggunakan metode elemen hingga terbagi menjadi beberapa tahapan, yaitu sebagai berikut:

1. Pembagian dan pemilihan tipe elemen;

2. Penentuan fungsi displasmen;

3. Penentuan hubungan strain - displacement dan stress strain;

4. Penurunan persamaan dan matriks kekakuan elemen;

Persamaan dan matriks kekakuan elemen diselesaikan menggunakan metode Galerkin, seperti dalam (4).

$$
\{f\}=[k]\{d\}
$$

Dimana, $\{f\}$ adalah vektor dari gaya noda elemen; dalam $\mathrm{N},[k]$ menyatakan matriks kekakuan elemen; dalam $\mathrm{N} / \mathrm{m}$, dan $\{d\}$ vektor dari derajat kebebasan noda elemen atau diambil nilai perpindahan noda; dalam $\mathrm{m}$.

5. Penurunan persamaan elemen untuk mendapatkan persamaan global dan kondisi batas;

Persamaan global dan kondisi batas diperoleh dengan menggunakan (5).

$$
\{F\}=[K]\{d\}
$$

Dimana, $\{F\}$ adalah vektor dari gaya noda secara global; dalam $\mathrm{N},[K]$ menyatakan matriks kekakuan elemen secara global; dalam $\mathrm{N} / \mathrm{m}$, dan $\{d\}$ vektor dari derajat kebebasan noda elemen atau diambil nilai perpindahan noda; dalam $m$.

6. Penyelesaian vektor dari derajat kebebasan;

7. Perhitungan regangan dan tegangan elemen; dan

8. Interpretasi hasil perhitungan.

\section{G. Analisis Elemen Hingga Dibantu Komputer}

Rujukan [6] menjelaskan proses pemodelan struktur menggunakan perangkat lunak berbasis elemen hingga yang terbagi menjadi tiga proses, yaitu sebagai berikut:

1. Pre-processor merupakan tahap awal pembuatan geometri model yang dimulai dari pemilihan tipe analisis, penentuan informasi material model, aplikasi beban dan 
kondisi batas pada geometri, sampai pembuatan mesh pada model;

2. Solver adalah tahap perhitungan komputasi dari kondisikondisi yang diaplikasikan ke geometri model; dan

3. Post-processor merupakan penampilan hasil perhitungan dari tahap sebelumnya dalam bentuk tampilan grafis.

\section{H. Konvergensi}

Metode elemen hingga merupakan sebuah teknik perhitungan numeris sehingga hasil yang didapatkan adalah nilai pendekatan dari hasil sesungguhnya. Seiring berkurangnya ukuran elemen, hasil yang didapatkan akan berbeda dan berurutan. Pendekatan perhitungan akan menghasilkan nilai yang konvergen dengan hasil sesungguhnya ketika kualitas mesh menginkat dan elemen yang dibentuk semakin banyak dengan ukuran yang lebih kecil [7].

\section{Tegangan Ijin Maksimum}

Rujukan [2] menjelasakan nilai maksimum yang diijinkan dalam perhitungan tegangan model struktur. Kriteria nilai yang diijinkan dibagi menjadi dua, yaitu untuk analisis kekuatan pada tangki muat secara umum, dan pada fine mesh zone. Nilai kriteria untuk kedua jenis analisis tersebut dapat dihitung menggunakan persamaan (6) dan (7).

$$
\begin{aligned}
& \lambda_{y}=\frac{\sigma_{v m}}{\sigma_{y d}} \\
& \lambda_{y}=\frac{k \times \sigma_{v m}}{235}
\end{aligned}
$$

Dimana, $\lambda_{y}$ adalah nilai yield utilisatin factor model, $\sigma_{v m}$ adalah nilai tegangan von misses pada model; dalam $\mathrm{N} / \mathrm{mm}^{2}, \sigma_{y d}$ menyatakan kuat tarik material model; dalam $\mathrm{N} / \mathrm{mm}^{2}$, dan $k$ menyatakan faktor material untuk baja dengan kekuatan lebih tinggi.

Untuk analisis kekuatan tangki muat secara umum, kriteria ditentukan menggunakan (6) dan nilainya tidak boleh lebih besar dari 0,64. Untuk analisis kekuatan pada fine mesh zone, kriteria ditentukan menggunakan (7) dan nilainya tidak boleh lebih besar dari:

1) 1,36 untuk elemen yang tidak terletak di sambungan las; dan

2) 1,2 untuk elemen yang terletak di sambungan las [2].

\section{PEMODELAN}

\section{A. Penentuan Variasi}

Analisis kekuatan sekat bergelombang dilakukan menggunakan beberapa variasi model sekat. Variasi dilakukan pada tinggi lower stool dan tebal diafragma sekat yang ditentukan berdasarkan ukuran konstruksi yang diperoleh dari data konstruksi kapal tanker 17500 LTDW. Variasi yang akan dianalisis ditunjukkan pada Tabel 1.

Tabel 1 menunjukkan variasi pada model sekat bergelombang. Terdapat 3 variasi tinggi lower stool, yaitu 1280, 895, dan $1790 \mathrm{~mm}$; serta 3 varaisi tebal diafragma, yaitu 14,13 , dan $11 \mathrm{~mm}$.
Dengan jumlah total 9 variasi yang ditunjukkan pada Tabel 1, kemudian dilakukan pembuatan model sekat bergelombang menggunakan perangkat lunak berbasis elemen hingga.

Tabel 1.

Variasi Tinggi Stool Dan Tebal Diafragma Model Sekat

\begin{tabular}{ccc}
\hline \hline Model & Tinggi Stool $(\mathrm{mm})$ & Tebal Diafragma Sekat $(\mathrm{mm})$ \\
\hline 1A & \multirow{2}{*}{1280} & 14 \\
1B & & 13 \\
1C & & 11 \\
\hline 2A & 895 & 14 \\
2B & & 13 \\
2C & \multirow{2}{*}{1790} & 11 \\
\hline 3A & & 14 \\
3B & & 11 \\
3C & & \\
\hline \hline
\end{tabular}

\section{B. Pembuatan Geometri}

Pembuatan geometri dilakukan menggunakan analisis struktur statis linier dan jenis material yang digunakan adalah baja A36. Tipe elemen yang digunakan adalah elemen shell untuk konstruksi sekat secara keseluruhan dan beam untuk penegar pada diafragma di dalam lower stool.

\section{Meshing}

Pembuatan mesh pada model bertujuan untuk membagi model menjadi elemen-elemen dalam ukuran yang lebih kecil. Ukuran mesh pada model sekat dibagi menjadi dua jenis, yaitu untuk sekat secara umum dengan ukuran minimal 385 x 385 $\mathrm{mm}$, dan untuk bagian yang termasuk dalam fine mesh zone dengan ukuran minimal 50 x $50 \mathrm{~mm}$.

\section{Proses Konvergensi}

Proses konvergensi dilakukan pada model dengan variasi tinggi lower stool (Model 1, 2, dan 3). Proses konvergensi menggunakan acuan jumlah elemen pada model. Hasil konvergensi model ditunjukkan pada Tabel 2.

Tabel 2.

Ukuran Mesh Model Sekat Hasil Proses Konvergensi

\begin{tabular}{cccc}
\hline \hline Model & Tinggi Stool $(\mathrm{mm})$ & Jumlah Elemen & Ukuran Mesh $(\mathrm{mm})$ \\
\hline \multirow{2}{*}{1} & \multirow{2}{*}{1280} & 115145 & $\begin{array}{c}150 \times 150 \\
45 \times 45\end{array}$ \\
\hline \multirow{2}{*}{2} & \multirow{2}{*}{895} & \multirow{2}{*}{116826} & $\begin{array}{c}125 \times 125 \\
42.5 \times 42.5\end{array}$ \\
\hline \multirow{2}{*}{3} & \multirow{2}{*}{1790} & \multirow{2}{*}{162813} & $\begin{array}{c}125 \times 125 \\
42.5 \times 42.5\end{array}$ \\
\hline \hline
\end{tabular}

\section{E. Penentuan Kondisi Batas}

Kodisi batas pada model ditentukan dengan variasi kondisi batas yang diaplikasikan pada Model 1, yang merupakan model dengan ukuran konstruksi seperti pada data kapal tanker 17500 LTDW. Dari variasi tersebut dilihat respon dan tegangan yang terjadi pada model jika diaplikasikan beban seperti pada kondisi sesungguhnya. Kondisi batas akan sesuai apabila respon dari model sekat menggambarkan kondisi sesungguhnya, serta nilai tegangan maksimum yang terjadi tidak melebihi nilai yang diijinkan. 


\section{ANALISIS DAN PEMBAHASAN}

\section{A. Tegangan Maksimum}

Dari proses simulasi yang dilakukan pada model sekat bergelombang, didapatkan nilai tegangan maksimum $\left(\sigma_{\text {maks }}\right)$ untuk setiap variasi, yang ditunjukkan pada Tabel 3 .

Tabel 3.

Nilai Tegangan Maksimum Untuk Setiap Variasi Model

\begin{tabular}{cccc}
\hline \hline Model & Tinggi Stool $(\mathrm{mm})$ & Tebal Diafragma Sekat $(\mathrm{mm})$ & $\sigma_{\text {maks }}(\mathrm{MPa})$ \\
\hline 1A & \multirow{2}{*}{1280} & 14 & 278 \\
1B & & 13 & 278 \\
1C & & 11 & 278 \\
\hline 2A & \multirow{2}{*}{895} & 14 & 366 \\
2B & & 13 & 366 \\
2C & \multirow{2}{*}{1790} & 11 & 367 \\
\hline 3A & & 14 & 223 \\
3B & 13 & 223 \\
3C & & 11 & 223 \\
\hline \hline
\end{tabular}

Seperti yang ditunjukkan pada Tabel 3 , nilai tegangan maksimum terbesar terjadi pada Model 2C, yaitu sebesar 367 $\mathrm{MPa}$, sedangkan nilai tegangan maksimum terkecil terjadi pada Model 3A, 3B, dan 3C dengan nilai yang sama sebesar $223 \mathrm{MPa}$. Pengaruh perubahan tinggi lower stool terhadap nilai tegangan maksimum dinyatakan pada Gambar 3, dan pengaruh perubahan tebal diafragma sekat terhadap nilai tegangan maksimum dinyatakan pada Gambar 4.

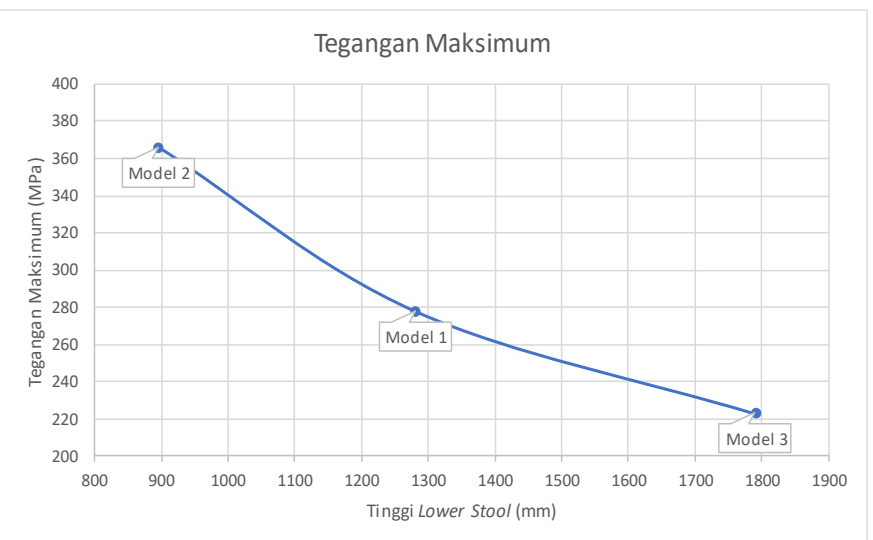

Gambar 3. Pengaruh perubahan tinggi lower stool terhadap nilai tegangan maksimum dengan tebal diafragma sekat $14 \mathrm{~mm}$

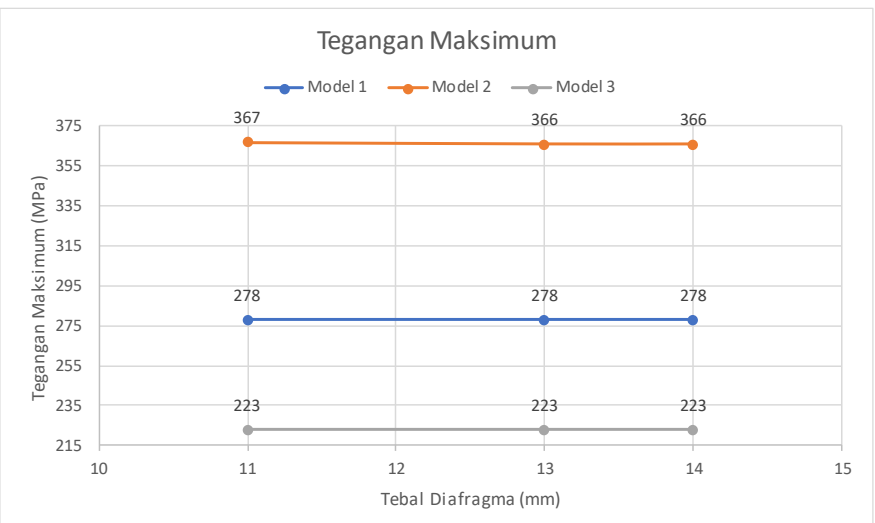

Gambar 4. Pengaruh Perubahan Tebal Diafragma Untuk Setiap Variasi Model Sekat Terhadap Nilai Tegangan Maksimum

Gambar 3 menunjukkan pengaruh perubahan tinggi lower stool ditinjau dari variasi model dengan tebal diafragma 14 $\mathrm{mm}$. Terlihat bahwa nilai tegangan maksimum terbesar terjadi pada model dengan tinggi lower stool $895 \mathrm{~mm}$. Tegangan maksimum berkurang dengan penambahan tinggi lower stool menjadi $1280 \mathrm{~mm}$. Pada variasi ini terlihat grafik membentuk lengkungan yang menyatakan bahwa pengurangan nilai tegangan maksimum mencapai nilai maksimal pada variasi ini. Nilai tegangan maksimum semakin berkurang seiring bertambahnya tinggi lower stool menjadi $1790 \mathrm{~mm}$.

Pada Gambar 4 dinyatakan pengaruh perubahan tebal diafragma terhadap nilai tegangan maksimum untuk setiap variasi model sekat. Terlihat bahwa pada Model 1 nilai tegangan tidak berubah. Pada Model 2 terjadi penurunan nilai tegangan pada kenaikan tebal diafragma dari $11 \mathrm{~mm}$ ke 13 $\mathrm{mm}$. Dan pada Model 3 tidak terjadi perubahan nilai tegangan dengan perubahan ketebalan diafragma sekat.

\section{B. Tegangan Ijin}

Tegangan maksimum yang diijinkan dihitung berdasarkan nilai yield utilisation factor $\left(\lambda_{y}\right)$. Untuk setiap model variasi, nilai yield utilisation factor dihitung menggunakan (7) karena tegangan maksimum terletak di dalam fine mesh zone. Hasil perhitungan yield utilisation factor untuk setiap variasi model ditunjukkan pada Tabel 4.

Tabel 4.

Nilai Yield Utilisation Factor Untuk Setiap Variasi Model

\begin{tabular}{ccccc}
\hline \hline Model & $\sigma_{\text {maks }}(\mathrm{MPa})$ & $\lambda_{\mathrm{y}}$ Model & $\lambda_{\mathrm{y}}$ Ijin & Keterangan \\
\hline 1A & 278 & 1,183 & 1,2 & Diterima \\
1B & 278 & 1,183 & 1,2 & Diterima \\
1C & 278 & 1,183 & 1,2 & Diterima \\
\hline 2A & 366 & 1,557 & 1,2 & Tidak diterima \\
2B & 366 & 1,557 & 1,2 & Tidak diterima \\
2C & 367 & 1,562 & 1,2 & Tidak diterima \\
\hline 3A & 223 & 0,949 & 1,2 & Diterima \\
3B & 223 & 0,949 & 1,2 & Diterima \\
3C & 223 & 0,949 & 1,2 & Diterima \\
\hline \hline
\end{tabular}

Tabel 4 menunjukkan bahwa untuk setiap variasi Model 1, nilai yield utilisation factor tidak melebihi nilai yang diijinkan. Pada Model 2, seluruh variasinya tidak diterima karena nilai yield utilisation factor melebihi nilai yang diijinkan. Untuk Model 3, nilai yield utilisation factor untuk setiap variasi model dibawah nilai yang diijinkan. Dapat disimpulkan bahwa semua variasi model sekat memenuhi nilai yield utilisation factor yang diijinkan kecuali pada seluruh variasi Model 2 .

\section{Deformasi Maksimum}

Nilai deformasi maksimum ( $\left.\delta_{\text {maks }}\right)$ yang terjadi pada model konstruksi sekat didapatkan dari proses simulasi model. Untuk setiap variasi model, nilai deformasi maksimum ditunjukkan pada Tabel 5.

Tabel 5.

Nilai Deformasi Maksimum Untuk Setiap Variasi Model

\begin{tabular}{cccc}
\hline \hline Model & Tinggi Stool $(\mathrm{mm})$ & Tebal Diafragma Sekat $(\mathrm{mm})$ & $\delta_{\text {maks }}(\mathrm{mm})$ \\
\hline 1A & & 14 & 8,275 \\
1B & \multirow{2}{*}{1280} & 13 & 8,278 \\
1C & & 11 & 8,283 \\
\hline 2A & 895 & 14 & 9,010
\end{tabular}




\begin{tabular}{|c|c|c|c|}
\hline $2 \mathrm{~B}$ & & 13 & 9,016 \\
\hline $2 \mathrm{C}$ & & 11 & 9,029 \\
\hline $3 \mathrm{~A}$ & & 14 & 6,886 \\
\hline $3 B$ & 1790 & 13 & 6,890 \\
\hline $3 \mathrm{C}$ & & 11 & 6,899 \\
\hline
\end{tabular}

Tabel 5 menunjukkan nilai deformasi maksimum terbesar terjadi pada Model 2C, sebesar 9,029 mm. Nilai deformasi maksimum terkecil terjadi pada Model 3A, yaitu sebesar 6,886 $\mathrm{mm}$. Pengaruh perubahan tinggi lower stool terhadap deformasi maksimum dinyatakan pada Gambar 5, dan pengaruh perubahan tebal diafragma sekat terhadap deformasi maksimum dinyatakan pada Gambar 6.

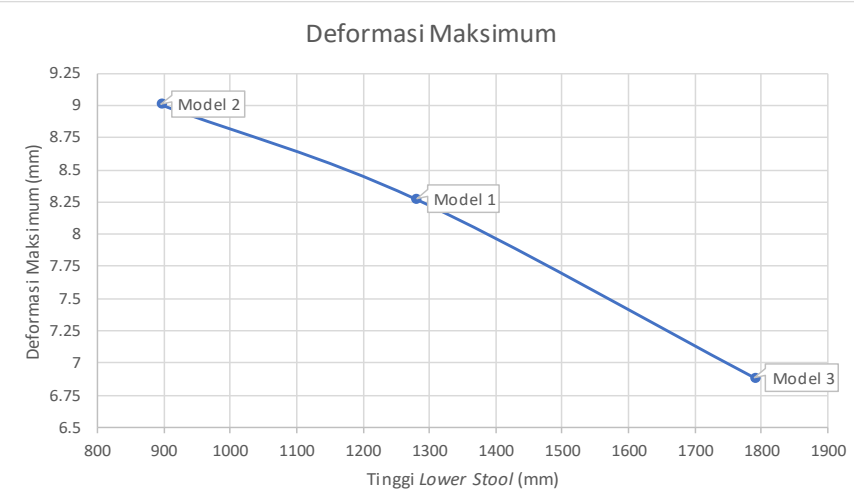

Gambar 5. Pengaruh perubahan tinggi lower stool terhadap nilai deformasi maksimum dengan tebal diafragma sekat $14 \mathrm{~mm}$

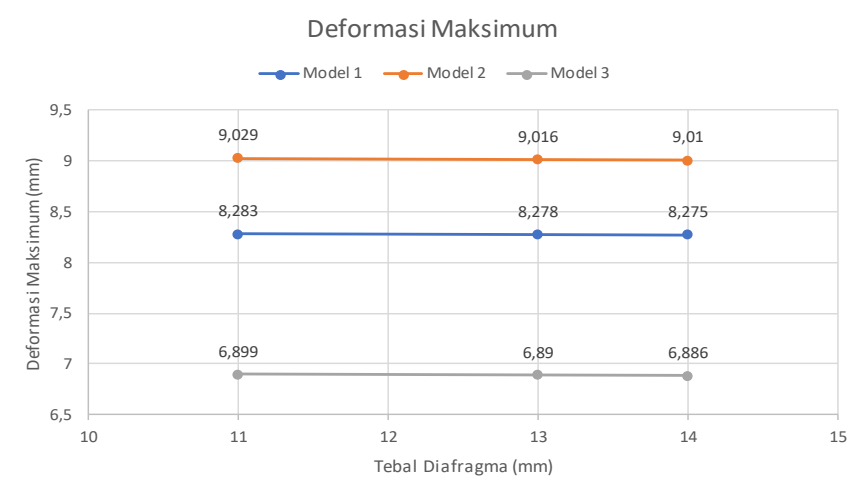

Gambar 6. Pengaruh perubahan tebal diafragma untuk setiap variasi model sekat terhadap nilai deformasi maksimum

Gambar 5 menunjukkan bahwa nilai deformasi maksimum terbesar terjadi pada Model 2 dengan tinggi lower stool 895 $\mathrm{mm}$. Dengan penambahan tinggi lower stool menjadi 1280 $\mathrm{mm}$, nilai deformasi maksimum berkurang. Pada variasi tinggi lower stool $1280 \mathrm{~mm}$, grafik membentuk lengkungan yang menyatakan pengurangan nilai deformasi maksimum akibat penambahan tinggi lower stool mencapai nilai minimal pada variasi ini. Deformasi maksimum semakin berkurang dengan penambahan tinggi lower stool menjadi $1790 \mathrm{~mm}$.

Pada Gambar 6 dinyatakan pengaruh perubahan tebal diafragma sekat terhadap nilai deformasi maksimum untuk setiap variasi model sekat. Pada Model 1, 2, dan 3 nilai deformasi maksimum berkurang seiring dengan penambahan ketebalan diafragma sekat dari $11 \mathrm{~mm}$ menjadi $14 \mathrm{~mm}$.

\section{Berat Konstruksi}

Berat konstruksi ( $\left.W_{\text {kons }}\right)$ model sekat bergelombang diperoleh melalui perhitungan komputasi bersamaan dengan proses simulasi model. Untuk setiap variasi model, berat konstruksi ditunjukkan pada Tabel 6.

Tabel 6.

Nilai berat konstruksi untuk setiap variasi model

\begin{tabular}{cccc}
\hline \hline Model & Tinggi Stool $(\mathrm{mm})$ & Tebal Diafragma Sekat $(\mathrm{mm})$ & $\mathrm{W}_{\text {kons }}(\mathrm{ton})$ \\
\hline 1A & \multirow{2}{*}{1280} & 14 & 59,921 \\
1B & & 13 & 59,669 \\
1C & \multirow{2}{*}{895} & 11 & 59,167 \\
\hline 2A & & 14 & 57,201 \\
2B & & 13 & 56,939 \\
2C & \multirow{2}{*}{1790} & 11 & 56,415 \\
\hline 3A & & 14 & 62,830 \\
3B & 13 & 62,589 \\
3C & & 11 & 62,110 \\
\hline \hline
\end{tabular}

Pada Tabel 6 ditunjukkan bahwa berat konstruksi terbesar terdapat pada Model 3A, yaitu sebesar 62,830 ton. Berat konstruksi terkecil terdapat pada Model 2C, yaitu sebesar 56,415 ton. Pengaruh perubahan tinggi lower stool terhadap berat konstruksi ditunjukkan pada Gambar 7, dan pengaruh perubahan tebal diafragma sekat terhadap berat konstruksi ditunjukkan pada Gambar 8.

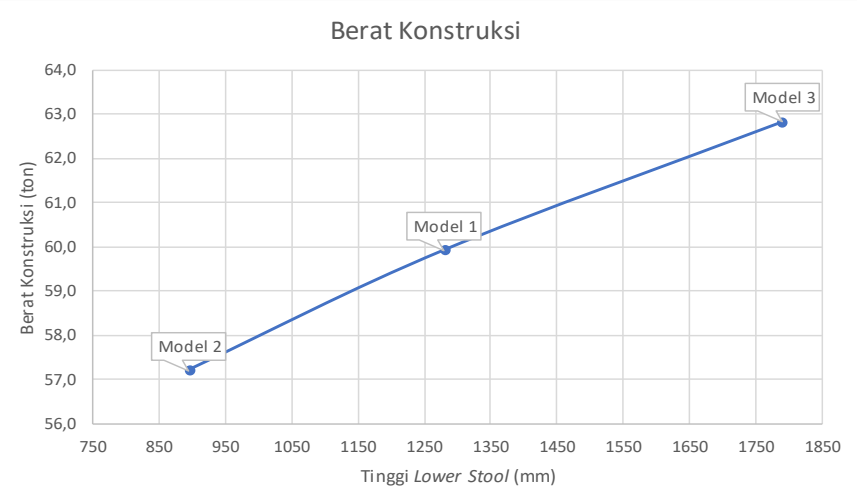

Gambar 7. Pengaruh perubahan tinggi lower stool terhadap berat konstruksi sekat dengan tebal diafragma $14 \mathrm{~mm}$

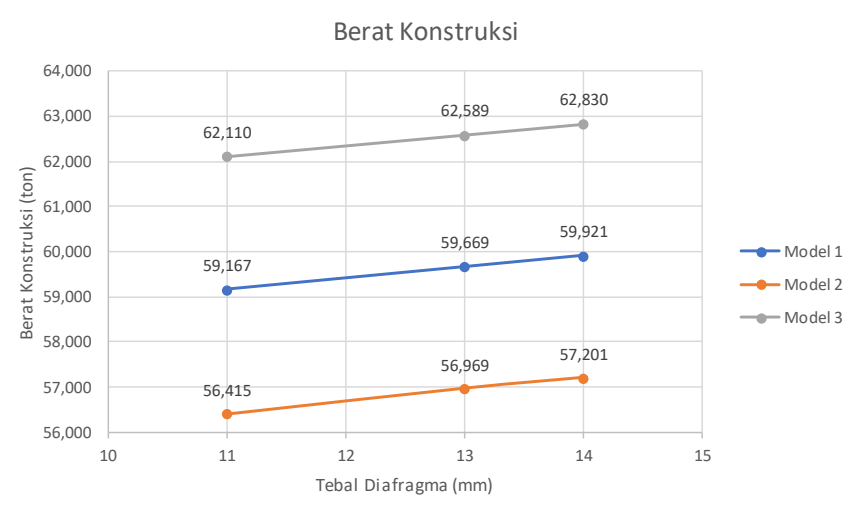

Gambar 8. Pengaruh perubahan tebal diafragma terhadap berat konstruksi untuk setiap variasi model

Gambar 7 menunjukkan berat konstruksi terbesar terdapat pada Model 3 dengan tinggi lower stool $1790 \mathrm{~mm}$. Dengan pengurangan tinggi menjadi $1280 \mathrm{~mm}$, berat konstruksi juga 
berkurang. Berat konstruksi semakin berkurang dengan pengurangan tinggi lower stool menjadi $895 \mathrm{~mm}$.

Pada Gambar 8 menunjukkan nilai berat konstruksi semakin berkurang seiring berkurangnya tebal diafragma untuk setiap variasi model. Berat konstruksi terbesar untuk setiap variasi model terdapat pada tebal diafragma sekat $14 \mathrm{~mm}$.

\section{E. Volume Konstruksi}

Volume konstruksi ( $\mathrm{V}_{\text {kons}}$ ) sekat bergelombang dihitung berdasarkan volume tangki muat yang hilang akibat pemasangan sekat bergelombang. Nilai volume konstruksi untuk setiap variasi model ditunjukkan pada Tabel 7.

Tabel 7.

Nilai volume konstruksi untuk setiap variasi model

\begin{tabular}{cccc}
\hline \hline Model & Tinggi Stool $(\mathrm{mm})$ & Tebal Diafragma Sekat $(\mathrm{mm})$ & $\mathrm{V}_{\text {kons }}\left(\mathrm{m}^{3}\right)$ \\
\hline 1A & \multirow{2}{*}{1280} & 14 & 79,644 \\
1B & & 13 & 79,612 \\
1C & \multirow{2}{*}{895} & 11 & 79,548 \\
\hline 2A & & 14 & 68,965 \\
2B & \multirow{2}{*}{1790} & 13 & 68,932 \\
2C & & 11 & 68,865 \\
\hline 3A & & 14 & 93,795 \\
3B & & 13 & 93,765 \\
3C & & 11 & 93,703 \\
\hline \hline
\end{tabular}

Tabel 7 menunjukkan volume konstruksi terbesar terdapat pada Model 3A, sebesar 93,795 $\mathrm{m}^{3}$. Volume konstruksi terkecil terdapat pada Model 2C, sebesar 68,865 $\mathrm{m}^{3}$. Pengaruh perubahan tinggi lower stool dan tebal diafragma sekat terhadap volume konstruksi model dinyatakan secara berurutan pada Gambar 9 dan Gambar 10.

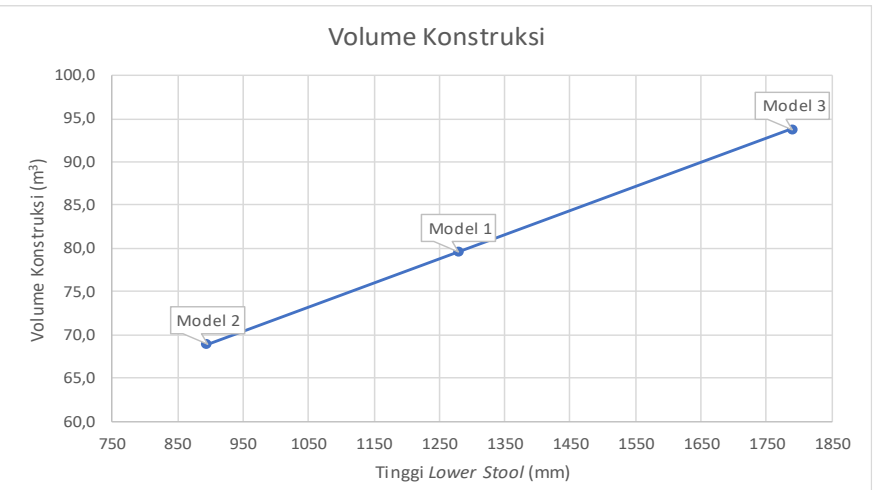

Gambar 9. Pengaruh perubahan tinggi lower stool terhadap volume konstruksi dengan tebal diafragma $14 \mathrm{~mm}$

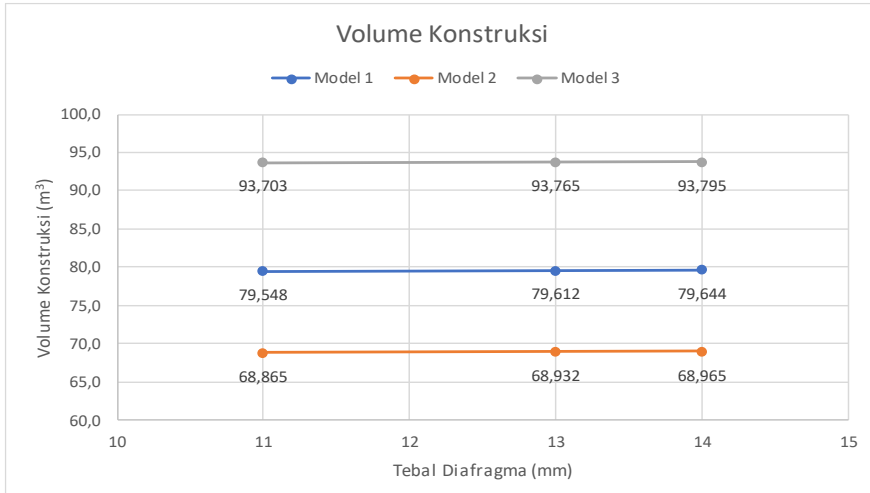

Gambar 10. Pengaruh perubahan tebal diafragma sekat terhadap volume konstruksi untuk setiap variasi model

Gambar 9 menunjukkan volume konstruksi terbesar pada Model 3 dengan tinggi lower stool $1790 \mathrm{~mm}$. Volume konstruksi berkurang seiring pengurangan tinggi lower stool menjadi $1280 \mathrm{~mm}$. Pengurangan tinggi lower stool menjadi $895 \mathrm{~mm}$ semakin mengurangi volume konstruksi model.

Gambar 10 menunjukkan volume konstruksi terbesar untuk setiap variasi model memiliki tebal diafragma $14 \mathrm{~mm}$. Volume konstruksi berkurang dengan berkurangnya tebal diafragma menjadi $13 \mathrm{~mm}$, dan semakin berkurang dengan pengurangan tebal difragma menjadi $11 \mathrm{~mm}$.

\section{KESIMPULAN}

Berdasarkan hasil analisis dan pembahasan maka dapat disimpulkan sebagai berikut:

1. Variasi model paling optimum terdapat pada Model $1 \mathrm{C}$ yang memiliki tinggi lower stool $1280 \mathrm{~mm}$ dan tebal diafragma $11 \mathrm{~mm}$ dengan tegangan maksimum $278 \mathrm{MPa}$, deformasi maksimum $8,283 \mathrm{~mm}$, berat kostruksi sebesar 59,167 ton, dan volume konstruksi 79,548 $\mathrm{m}^{3}$

2. Tegangan maksimum terkecil terjadi pada tinggi lower stool $1790 \mathrm{~mm}$ dan terbesar pada ketinggian $895 \mathrm{~mm}$, sedangkan perubahan tebal diafragma tidak berpengaruh terhadap tegangan maksimum model

3. Deformasi maksimum terkecil terjadi pada tinggi lower stool $1790 \mathrm{~mm}$ dan terbesar pada tinggi $895 \mathrm{~mm}$, pada variasi tebal diafragma sekat nilai terkecil terjadi pada ketebalan $14 \mathrm{~mm}$ dan terbesar pada tebal $11 \mathrm{~mm}$

4. Model yang memiliki berat konstruksi terkecil memiliki tinggi lower stool $895 \mathrm{~mm}$ dengan tebal diafragma $11 \mathrm{~mm}$, dan berat konstruksi terbesar memiliki tinggi lower stool $1790 \mathrm{~mm}$ dengan tebal diafragma $14 \mathrm{~mm}$

5. Volume konstruksi terkecil terdapat pada model dengan tinggi lower stool $895 \mathrm{~mm}$ dan tebal diafragma $11 \mathrm{~mm}$, sedangkan volume konstruksi terbesar terdapat pada model dengan tinggi $1790 \mathrm{~mm}$ da tebal diafragma $14 \mathrm{~mm}$.

\section{DAFTAR PUSTAKA}

[1] M. M. and T. O. Y. Okumoto, Y. Takeda, "Design of Ship Hull Structures: A Practical Guide for Engineers," Springer, 2008.

[2] I. A. of C. S. (IACS), Common Structural Rules for Double Hull Oil Tanker (CSR). London: IACS Publishing, 2012.

[3] S. Konstantinos, "Structural Design of Modern Chemical Tankers," 
National Technical University of Athens, 2015.

[4] E. A. Stokoe, Reed's Ship Construction for Marine Students. Surrey, Enland: Thomas Reed Publications, 1996.

[5] D. L. Logan, A First Course in The Finite Element Method. Platteville: University of Wisconsin, 2005.

[6] K. N. Hoque, "Analysis of Structural Discontinuities in Ship Hull Using Finite Element Method," 2013.

[7] S. S. Rao, "The Finite Element Method in Engineering, 5th ed," Massachusetts: Elsevier, 2011. 